\title{
Prevalence of Salmonella spp. in fresh fish and shrimp in Semarang's Traditional Markets (Indonesia) through Polymerase Chain Reaction
}

\author{
ULFAH AMALIA ${ }^{\varphi}$, Y. S. DARMANTO \\ Department of Fish Product Technology, Faculty of Fisheries and Marine Sciences, Universitas Diponegoro. Jl. Prof. Sudarto, SH, Tembalang, Semarang \\ 50275, Central Java, Indonesia. Tel.: +62-24-7474698, Fax.: +62-24-7474698, •email: ulfah.amalia@ @live.undip.ac.id \\ Manuscript received: 17 March 2020. Revision accepted: 13 May 2020.
}

\begin{abstract}
Amalia U, Darmanto YS. 2020. Prevalence of Salmonella spp. in fresh fish and shrimp in Semarang's Traditional Markets (Indonesia) through Polymerase Chain Reaction. Biodiversitas 21: 2500-2505. Fresh fish products are rich in macronutrients for meeting the protein needs of the consumer's community. Semarang is a city located in the North Coast of Java, indirectly closely related to the production of catches and processed fish and shrimp, including several large markets in Semarang, e.g.: Rejomulyo, Jatingaleh, and Rasamala. The problem was that there are still many fresh fish and shrimp traders in traditional markets who did not understand how to handling of fresh fish and shrimp properly so that it triggers the growth of bacteria, one of which is Salmonella spp. Indonesian National Standard requires that Salmonella must be negative in food, because these bacteria are pathogenic. Generally, detection of Salmonella in food using conventional methods requires 5 days. This study aims to determine how far the prevalence of Salmonella in fresh fish and shrimps in three traditional markets in Semarang through Polymerase Chain Reaction, Real-Time PCR compare with conventional methods. The results showed that 4 out of 9 fresh fish samples (44\%) and also 5 out of 9 fresh shrimp samples (55.6\%) in three traditional markets in Semarang was contaminated by Salmonella spp through conventional method; while all of samples (100\%) was detected Salmonella spp using PCR.
\end{abstract}

Keywords: Fish, PCR, prevalence, Salmonella, shrimp

\section{INTRODUCTION}

Fishery products have been widely used as protein sources and non-oil export commodities. CSDMFFI (2019) recorded that until the end of the year export of fishery products towards the end of 2018 reached US \$ 5 billion, up 10 from 2017 which amounted to US \$ 4.52 billion. Shrimp became the main commodity, which reached US \$ 1.8 billion, with a volume of 180,000 tons. In Central Java, shrimp's distribution has increased from January to August 2018. The export increased is also driven by the awareness of stakeholders, especially suppliers of fishery processing raw materials-in meeting the requirements for quality control certificates to support export transactions abroad. This indicates that the quality assurance of Central Java's exported fishery products is also increasingly gaining recognition in the international market. However, besides export orientation, the distribution of fishery products in the form of fresh fish and shrimp is also spread in several traditional markets in Semarang. For example, Rejomulyo Market or better known as Kobong Market, has a high activity of buying and selling fresh fishery products. Many fish traders from various cities in the province of Central Java such as Kendal, Salatiga buy fish in the market to be resold in their home city. Likewise, the presence of fresh fish and shrimp in Jatingaleh Market and Rasamala Market, Banyumanik to meet household needs in the upper and surrounding Semarang region. The quality and sanitation standards applied for fresh fishery products to be consumed are actually the same, but there are still many fish and shrimp traders found in traditional markets that have not applied the basic principles of sanitation and proper handling of fishery products. This can accelerate the process of deterioration in the quality of fresh fish and shrimp that begins with the growth of bacteria, one of which is Salmonella spp.

Prevalence of Salmonella spp. on fresh fish and fisheries products from South East Asia's countries has been reported, such as in 2011 USFDA, Kumar et. al. (2015) and Maritsa et. al. (2018) found the prevalence of Salmonella spp on fish and fresh chicken sold in traditional market around Jambi University. Semarang as a big city also has high activity related fresh fisheries market, especially in 3 big traditional market, i.e: Rejomulyo, Jatingaleh, and Rasamala's markets. Generally, for verifying the quality, guarantee system has done by final product assays, so the product standardization has fulfilled. Even though safety couldn't be guaranteed, product assays could be convinced the consumers. Salmonella spp. 's assays by conventional method generally require long time. By technology, many methods have been developed. Salmonella spp.'s detection method based on PCR has been reported by Amalia et. al. (2014), Jeyasekaran et al. (2012), and Upadhyay et. al. (2010). This study aims to know the sensitivity of conventional method, PCR and Real-Time PCR related Salmonella's prevalence detection in fresh fish and shrimp at 3 big markets in Semarang city, Central Java, Indonesia. 


\section{MATERIALS AND METHODS}

\section{Study area}

Sample used for this study were fresh fish and shrimp obtained from traditional market (Jatingaleh, Rasamala, and Rejomulyo) in Semarang, Central Java, Indonesia.

\section{Procedures}

Sample collection and bacterial enrichment

Positive control used Salmonella Typhimurium obtained from Medical Lab, Diponegoro National's Hospital and also media for conventional detection method such as Buffered Peptone Water (BPW) (Oxoid, England), Rappaport-Vassiliadis Broth (RVB), Muller-Kauffmann Tetrathionate-Novobiocin Broth (MKTtnB), Brilliance Salmonella Agar (BSA) and Xylose Lysine Deoxycholate Agar (XLDA), Triple Sugar Iron Agar (TSIA), Lysine Iron Agar (LIA); biochemical assays Microgen GN-ID Test Kit; rapid detection methods: PCR Master Mix (Fermentas), sterile distilled water, DNA template, and primer targeting invA of Salmonella obtained from AIT-Biotech (Singapore).

\section{Salmonella spp. identification}

Fresh fish and shrimp samples were taken from three traditional markets in Semarang. Pre enrichment of the sample was carried out by putting $25 \mathrm{~g}$ of each sample (minced fish meat and minced shrimp meat) into $225 \mathrm{ml}$ of BPW and incubated at $37^{\circ} \mathrm{C}$ for $18 \mathrm{~h}$. RVB is incubated at $41.5^{\circ} \mathrm{C}$ for $24 \mathrm{~h}$ and the MKTtn Broth at $37^{\circ} \mathrm{C}$ for $24 \mathrm{~h}$. Respectively, followed by selective media of XLDA and BSA and incubated for $24 \mathrm{~h}$ at $37^{\circ} \mathrm{C}$. For confirmation, colonies of presumptive Salmonella are subcultured and their identity is confirmed by TSIA and LIA.

\section{DNA Isolation for PCR}

DNA was isolated from $1 \mathrm{~mL}$ aliquots of overnight bacterial culture in Tryptone Soya (TSB) (LP0042, OXOID). In brief, one $\mathrm{mL}$ aliquot of bacterial culture is centrifugated at $4,000 \mathrm{x} \mathrm{g}$ for $10 \mathrm{~min}$ and the cell pellets were suspended in $190 \mu \mathrm{L}$ TE Buffer (Invitrogen) and 10 $\mu \mathrm{L}$ Lysozyme (Invitrogen) and incubated at $30^{\circ} \mathrm{C}$ for 30 $\mathrm{min}$. The cell suspension is centrifugated at 4,000 $\mathrm{x}$ g for 5 min and the cell pellets were resuspended in $400 \mu \mathrm{L}$ of DNA Lysis Buffer $T$ (Invitrogen), added with $20 \mu \mathrm{L}$ Proteinase K (Invitrogen), $15 \mu \mathrm{L}$ RNaseA (Promega) and mixed well by brief vortexing. The mixture was incubated at $70^{\circ} \mathrm{C}$ for $30 \mathrm{~min}$ and $200 \mu \mathrm{L}$ of DNA Binding Buffer (Invitrogen) was added. Purification was conducted by adding the mixture into spin column and centrifugation at $10,000 \mathrm{x} g$ for $1 \mathrm{~min}$. The spin column containing solid phase was moved to new tubes, added with $650 \mu \mathrm{L}$ DNA Wash Buffer (Invitrogen) contained $100 \%$ ethanol and centrifuged at $10,000 \mathrm{x}$ g for $10 \mathrm{~min}$. the spin column was placed in a new sterile $1.5 \mathrm{~mL}$ microcentrifuge tube and added with $50 \mu \mathrm{L}$ DNA Elution Buffer (Invitrogen) incubated at room temperature for $3 \mathrm{~min}$. DNA precipitation was carried out by centrifugation at $6,000 \mathrm{x}$ g for $1 \mathrm{~min}$. To recover more DNA, a second elution step was performed using the same volume of the same elution buffer. The clear supernatant (DNA) was collected and stored at $-20^{\circ} \mathrm{C}$ for PCR. The concentration of DNA was determined by optical density (OD) at the wavelength of $260 \mathrm{~nm}$ and its purity was evaluated by the ratio of $\mathrm{OD}$ at the wavelength of $260 / 280$. The DNA were kept at $-20^{\circ} \mathrm{C}$ until further use.

\section{PCR assays}

The specific primer for PCR assays used a forward primer F139 (5'- GTGAAATTATCGCCACGTTCGGG CAA - 3') and a reverse primer R141 (5' TCATCGCACCGYCAAAGGAACC - 3'). This primer amplify gene encoding for invA located within 287 to 312 and 571 to 550 bp regions (AIT-Biotech Singapore). PCR amplification was performed with PCR Applied Biosystem 2720 Cycler using PCR mixtures containing $1.5 \mu \mathrm{L}$ of primers, 7.5 $\mu$ LPCR Master Mix. The thermocycling condition were $95^{\circ} \mathrm{C}$ for $1 \mathrm{~min}$, followed by 35 cycles of denaturation at $95^{\circ} \mathrm{C}$ for $30 \mathrm{sec}$, annealing at $64.5^{\circ} \mathrm{C}$ for 30 sec and elongation at $72^{\circ} \mathrm{C}$ for $30 \mathrm{sec}$, with final extension at $72^{\circ} \mathrm{C}$ for $4 \mathrm{~min}$. The PCR products were visualized by electrophoresis on $1.5 \%$ agarose gel (Fermentas, USA) at $100 \mathrm{~V}$ for $30 \mathrm{~min}$, stained with SYBR SAFE $(0.6 \mu \mathrm{g} / 100$ $\mathrm{mL}$ ), visualized under UV transilluminator (Bio-Rad) and photographed. DNA of $S$. Typhimurium and sterile aquabidest were used as positive and negative control, respectively.

\section{Real-time PCR assays}

The PCR products $(400 \mu \mathrm{L})$ were used in PCR assays was transferred to a $1.5 \mathrm{~mL}$ microtube containing $100 \mu \mathrm{L}$ $\mathrm{ddH}_{2} \mathrm{O}$ solution and $0.5 \%$ saponin solution in $1 \mathrm{~mL}$ of 10 fold dilutions of PBS (Phosphate-Buffered Saline), then stored at $4^{\circ} \mathrm{C}$ for 24 hours. The stored sample was centrifuged at 12,000 rpm for 10 minutes, then discarded the supernatant. $1 \mathrm{~mL}$ of PBS solution was added to the microtube and centrifuged at $12,000 \mathrm{rpm}$ for 5 minutes, then discarded the supernatant. $100 \mu \mathrm{L}$ of $\mathrm{dd}_{2} \mathrm{O}$ solution and $50 \mu \mathrm{L}$ of $20 \%$ Chelex were added to the microtube, then incubated at $90^{\circ} \mathrm{C}-100^{\circ} \mathrm{C}$ for 10 minutes and vortex. The sample was then centrifuged at $12,000 \mathrm{rpm}$ for 10 minutes and a $1 \mathrm{~mL}$ supernatant was transferred to a new microtube and stored at $-20^{\circ} \mathrm{C}$ before use.

\section{RESULTS AND DISCUSSION}

\section{Salmonella spp.'s detection on fresh fish and shrimp by conventional methods}

The results showed that from each of the 9 fish samples and 9 fresh shrimp samples grown on TSB media, all showed turbidity (positive). The next stage is selective enrichment by using two types of media namely MullerKauffmann Tetrathionate-Novobiocin Broth (ISO) (MKTtn) and Rappaport Vassiliadis (RV). Both of these media selectively enriched the amount of Salmonella found in the sample, all of them showed positive results, in the form of turbidity and precipitation on MKTtn media and turbidity on RV media. In MKTtn media, selective compounds in the form of bile salts inhibit the growth of 
gram-positive bacteria. Novobiocin supplement contained in the media can increase Salmonella growth. In addition there are selective compounds such as sodium thiosulfate and tetrathionate to inhibit the growth of coliform bacteria. Tetrathionate is formed in the media due to the addition of iodine and potassium iodide $\left(\mathrm{I}_{2}-\mathrm{KI}\right)$. On MKTtn media, Salmonella can grow because it has the enzyme tetrathionate reductase (Post 1997). The presence of the tetrathionate reductase enzyme in Salmonella causes Salmonella to be resistant to the toxic effects of tetrathionate $\left(\mathrm{S}_{4} \mathrm{O}_{6}{ }^{2-}\right)$ during enrichment. On $\mathrm{RV}$ media selective compounds such as malachite green and magnesium chloride combined with a low $\mathrm{pH}(5.2 \pm 2)$ inhibit the growth of natural microbes originating from the digestive tract other than Salmonella (D'Aoust 1989). In addition, the growth of Salmonella is also supported by the presence of soy peptone in the media. The soy peptone contained in the RV media serves as a source of nitrogen, carbon, and amino acids for Salmonella.

Salmonella's isolation was then performed using two specific media namely Xylose Deoxycholate Agar (XLDA), and Brilliance Salmonella Agar (BSA). Typical colonies on XLDA media were pink with or without black in the middle, some appeared as large, shiny black colonies in the center or appeared as colonies that were all black (BAM 2017). Typical colonies in BSA were purple. Around the colony usually be blue at first and became black with increasing incubation time, which is called the halo effect. Typical or non-typical Salmonella colonies isolated from XLDA and BSA media were then inoculated on agar media to tilt Triple Sugar Iron Agar (TSIA) and Lysine Iron Agar (LIA) for biochemical confirmation by means of scratches and pricks, then their growth was observed after incubation at $35 \pm 2^{\circ} \mathrm{C}$ for 24 hours. The biochemical confirmation of TSIA was marked by the formation of red on the surface and yellow (producing acid) at the bottom of the tube, with or without gas forming on the agar. The red color occurred because Salmonella can ferment a limited amount of glucose in the media, so that if the glucose runs out this bacterium uses peptone as an energy source that occurs on the surface of the agar and produces a byproduct in the form of a base (red). The formation of $\mathrm{H}_{2} \mathrm{~S}$ was marked in black because the sodium thiosulfate content in order to be reduced by $\mathrm{H}_{2} \mathrm{~S}$ which then reacts with iron salt produces a black color. Biochemical confirmation in LIA was marked by the formation of purple on the surface and black on the bottom of the tube (producing $\mathrm{H}_{2} \mathrm{~S}$ ). The purple color occured because Salmonella can decarboxylized lysine to produce cadaverine amine, which was indicated by changing the purple bromchresol $\mathrm{pH}$ indicator to purple color. Table 1 shows the results that the media that produced the most positive biochemical confirmation tests on fresh fish samples were typical and atypical colonies from BSA from both MKTTn and RV selective enrichment media, where 4 and 5 of 9 fresh shrimp fish samples respectively (44.4\%) originating from MKTTn and RV were suspected to be Salmonella. And for the results of the media that most produce positive biochemical confirmation tests on fresh shrimp samples are typical and atypical colonies from XLDA from MKTTn and RV selective enrichment media, where each of 5 out of 9 fresh shrimp samples $(55.6 \%)$ originating from MKTTn and RV suspected Salmonella.

Based on Table 1, it appeared that the highest possibility of getting a colony suspected by Salmonella in fish is to isolate the colony from both BSA media and XLDA media, both from RV and MKTTn add-on media; whereas in fresh shrimp by isolating the colony from XLDA media. In this case, XLDA media was more sensitive to isolate Salmonella in shrimp compared with BSA media. Research related to the identification of Salmonella in several food and non-food objects in the past five years using XLDA media as a selective media, as conducted by (Albino et al. 2014; Yhils et al. 2015; Oni et al. 2016; Hasan et al. 2018 and Terfassa et al. 2018). XLDA media is used as a selective media, together with media such as Brain Heart Infussion Agar (BSIA), Brilliant Green Agar (BGA) and Brilliance Salmonella Agar (BSA). Typical colonies on XLDA media are pink with or without black in the middle, some will appear as large, shiny black colonies in the center or appear as colonies that are all black (BAM 2007). Typical colonies in BSA are purple. Around the colony will usually be blue at first and will become black with increasing incubation time, which is called the halo effect.

Table 1. Percentage of Salmonella presumptive colonies after TSIA LIA's confirmation

\begin{tabular}{|c|c|c|c|c|c|}
\hline \multirow[t]{2}{*}{ Information } & \multirow[t]{2}{*}{ Colonies } & \multicolumn{2}{|c|}{$\begin{array}{c}\text { Selective agar } \\
\text { media }\end{array}$} & \multicolumn{2}{|c|}{$\begin{array}{l}\sum \text { positive samples of TSIA } \\
\text { LIA and it's sensitivity }\end{array}$} \\
\hline & & BSA & XLDA & BSA & XLDA \\
\hline \multicolumn{6}{|l|}{ Total samples of fresh fishes $=9 ;$ fresh shrimps $=9$} \\
\hline \multirow{2}{*}{$\begin{array}{l}\text { Total fresh fish samples of Salmonella spp presumptive on selective } \\
\text { enrichment by RV media }\end{array}$} & Tipical & 6 & 5 & \multirow[t]{2}{*}{$4(44.4 \%)$} & \multirow[t]{2}{*}{$4(44.4 \%)$} \\
\hline & Atipical & 3 & 4 & & \\
\hline \multirow{2}{*}{$\begin{array}{l}\text { Total fresh shrimp samples of Salmonella spp presumptive on } \\
\text { selective enrichment by RV media }\end{array}$} & Tipical & 5 & 6 & \multirow[t]{2}{*}{$2(22.2 \%)$} & \multirow[t]{2}{*}{$5(55.6 \%)$} \\
\hline & Atipical & 4 & 3 & & \\
\hline \multirow{2}{*}{$\begin{array}{l}\text { Total fresh fish samples of Salmonella spp presumptive on selective } \\
\text { enrichment by MKTtn media }\end{array}$} & Tipical & 6 & 7 & \multirow[t]{2}{*}{$5(55.6 \%)$} & \multirow[t]{2}{*}{$5(55.6 \%)$} \\
\hline & Atipical & 3 & 2 & & \\
\hline \multirow{2}{*}{$\begin{array}{l}\text { Total fresh shrimp samples of Salmonella spp presumptive on } \\
\text { selective enrichment by MKTtn media }\end{array}$} & Tipical & 5 & 6 & \multirow[t]{2}{*}{$4(44.4 \%)$} & \multirow[t]{2}{*}{$5(55.6 \%)$} \\
\hline & Atipical & 4 & 3 & & \\
\hline
\end{tabular}



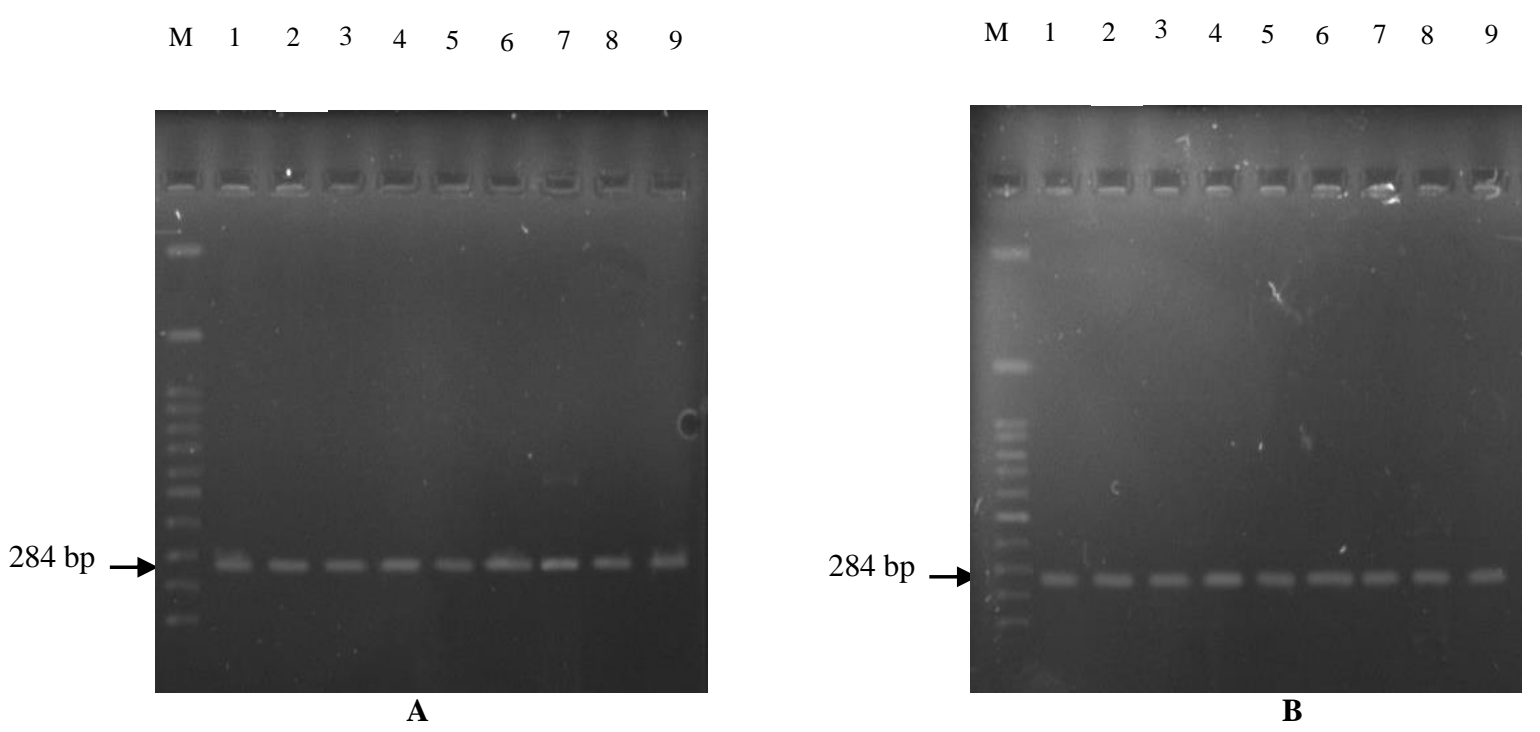

Figure 1. DNA Visualization of Amplification Salmonella's inv A genes on 1.5\% agarose. A. Line 1-9: fresh fish samples (all positive results); line M : marker DNA ladder 100 bp. B. Line 1-9: fresh shrimp samples (all positive results); line M : marker DNA ladder 100 bp

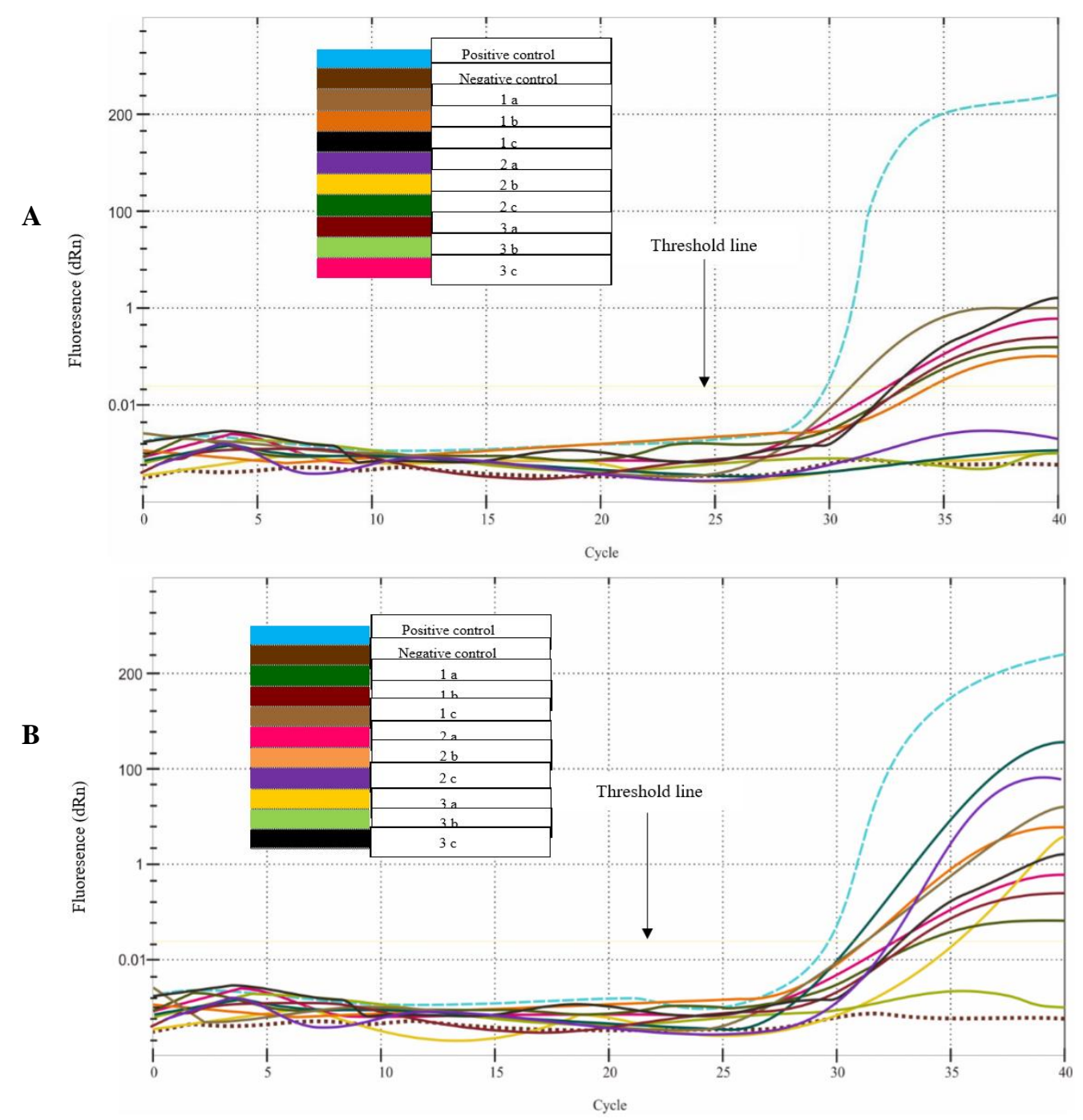

Figure 2. A. Amplification curve of fresh fish samples from 3 big traditional markets (each market consisted of 3 different seller: a, b, and c); B. Amplification curve of fresh shrimp samples from 3 big traditional markets (each market consisted of 3 different seller: $a, b$, and c) 
Table 2. Identification results of 11 non-Salmonella bacteria on fresh fishes and shrimps

\begin{tabular}{cllc}
\hline $\begin{array}{c}\text { Total } \\
\text { samples }\end{array}$ & Fish/shrimp & \multicolumn{1}{c}{$\begin{array}{c}\text { Bacteria } \\
\text { identified }\end{array}$} & $\begin{array}{c}\text { Probability } \\
\text { percentage } \\
(\%)\end{array}$ \\
\hline 5 & 3 in fish and 2 & Proteus mirabilis & $96-98.9$ \\
& in shrimp & Enterobacter aerogenes & 35.57 \\
3 & Fish & Enteridencia rettgeri & $75-99.9$ \\
1 & Shrimp & Providia rubidea & $70-82$ \\
1 & Shrimp & Serratia rum & 80.85 \\
1 & Shrimp & Proteus vulgaris & \\
\hline
\end{tabular}

Positive results on TSIA and LIA media were subsequently confirmed by the Microgen GN-ID System device with GNA microwell test strips to confirm it as Salmonella. The GN-ID Microgen Device System microwell test strips GNA is a rapid test kit to identify bacteria in the family of Enterobacteriaceae and certain Gram-negative bacteria by making it easy to inoculate and read relevant test results. Test results with Microgen GNID System showed that 4 out of 9 fresh fish samples (44.4\%) were Salmonella spp., with a very good final identification (80.89\%). In fresh shrimp found 5 out of 9 samples $(55.6 \%)$ Salmonella identified with very good final identification $(81.95 \%)$. Each of the remaining samples (6 fish and 5 shrimp) were confirmed to be Salmonella spp. Identification of 11 types of bacteria based on these advanced biochemical tests is presented in Table 2 .

\section{Salmonella spp. 's detection on fresh fish and shrimp by PCR methods}

Detection results of the prevalence of Salmonella spp. in each of the 9 fresh fish and shrimp samples by PCR method is shown in Figure 1.

From the 18 fresh fish and shrimp samples tested by PCR, the results were obtained that all were contaminated by pathogenic Salmonella bacteria (100\%). In this study, this indicated that PCR was more sensitive to detecting the presence of Salmonella through the invA gene amplification at 284 bp compared to conventional methods $(50 \%)$. These results are similar to the research conducted by Upadhyay et al. (2010), who compared several enrichment media used before the PCR test, and concluded that the enrichment stage was very important and potential to obtain a higher detection rate, because it increased the number of cells, including DNA and mRNA. The results showed that 11 fresh fish and shrimp samples were negative Salmonella when tested by conventional methods, but positive with PCR indicated that Salmonella might be viable but not cultured (El-Safey 2013). This is because conventional methods are able to detect Salmonella only through living cells, which should be quantitatively calculated, can be resuscitated in pre-enrichment and selective enrichment. The amount of DNA needed to detect Salmonella spp. in fresh shrimp using more conventional methods, compared with the PCR method. However, the sensitivity of the PCR method is higher compared to conventional methods. The existence of Salmonella spp. fresh fish and shrimp samples in traditional markets could be due to poor traditional market sanitation and hygiene practices. The main factor that allows Salmonella spp. in fish, fresh shrimp and other seafood found in traditional markets is Salmonella spp. from the digestive tract of humans or animals in the traditional market, because Salmonella's main habitat is the intestinal tract of animals and humans (Hasan et al. 2018). Moreover, it can also be caused by water used to wash shrimp, equipment used such as knives, cutting boards, containers and contamination from workers and cross contamination from other foodstuffs during storage.

\section{Salmonella spp. 's detection on fresh fish and shrimp by RT-PCR methods}

The results of detection of Salmonella spp prevalence in fresh fish and shrimp using the Real Time (RT) -PCR method were presented in Figures $2 \mathrm{a}$ and $2 \mathrm{~b}$.

Figures $2 \mathrm{a}$ and $2 \mathrm{~b}$ show that with RT PCR, Salmonella spp's DNA in fresh fish and shrimp, the average threshold can be detected between 30 - 35 annealing cycles. This suggests that the primers used to detect the presence of the Salmonella spp gene are appropriate, whereas in this study the primary pair F 139 - R 140 encoding the Salmonella spp invA gene was used. These results are in line with research conducted by Nurjanah et al. (2018) and Amalia et al. (2014), in which both studies also used the same primers to detect the presence of Salmonella spp's DNA.

\section{ACKNOWLEDGEMENTS}

Authors thanks to Faculty of Fisheries and Marine Science, Diponegoro University, Semarang, Indonesia for funding this research through Others APBN DPA SUKPA finance year of 2019 .

\section{REFERENCES}

Albino LAA, Rostagno MH, Húngaro H M, Mendonça RCS. 2014. Isolation, characterization, and application of bacteriophages for Salmonella spp. biocontrol in pigs. Foodborne Pathog Dis 11 (8): 602-609.

Amalia U, Dewanti R, Poernomo A. 2014. Rapid detection of Salmonella spp in Shrimp by Polymerase Chain Reaction (PCR). J Teknologi dan Industri Pangan 25 (1). DOI: 10.6066/jtip.2014.25.1. [Indonesian]

BAM [Bacteriological Analytical Manual]. 2017. Salmonella. http://www.cfsan.fda.gov/ ebam/bam-5.html (20 April 2020).

CSDMMFI [Center of Statistic Data and Ministry of Marine and Fisheries's Information]. 2019. Export Statistic of Fisheries Products 2019. Ministry of Marine and Fisheries, Jakarta, Indonesia.

D’Aoust JY. 1989. Salmonella. In: Doyle MP (ed.). Foodborne Bacterial Pathogens. Marcel Dekker Inc., Basel.

El-Safey EM. 2013. Incidence of Salmonella heidelberg in some Egyptian foods. Intl J Microbiol Immunol Res 1 (2): 16-25.

Hasan M, Kabir SML, Rahman Md. T, Sarker YA. 2018. Bacteriological quality assessment of buffalo meat collected from different districts of Bangladesh with particular emphasis on the molecular detection and antimicrobial resistance of the isolated Salmonella species. Asian Australas J Food Saf Secur 2 (1): 12-20.

ISO [International Standard Organization]. 2017. Microbiology of the food chain-Horizontal method for the detection, enumeration and serotyping of Salmonella (6579-1: 2017). 
Jeyasekaran G, Kannan TR, Robinsondhas JS, Albin JT, Durai RS. 2012 Detection of Salmonella enteric serovars in shrimps in eight hours by multiplex PCR assay. Ann Microbiol 62: 225-231.

Kumar R, Tirtha KD, Kuttanappilly VL. 2015. Salmonella grows vigorously on seafood and expresses its virulence and stress genes at different temperature exposure. BMC Microbiol 15: 254. DOI: 10.1186/s12866-015-0579-1.

Maritsa H, Aini F, Saputra A, Nurhakim D, Sihombing G. 2018. Isolation and identification Salmonella spp contaminant on chicken meat and fresh fish. Bio-Site Biologi dan Sains Terapan 3 (2): 61-64. DOI: 10.22437/bs.v3i2.4427. [Indonesian]

Nurjanah S, Rahayu WP, Mutaqin LS. 2018. Detection method for Salmonella typhimurium and Salmonella enteritidis using Real-Time Polymerase Chain Reaction. Intl J Eng Technol 7: 302-306.

Oni RA, Lambertini E, Buchanan RL. 2016. Assessing the potential for Salmonella growth in rehydrated dry dog food. Food Contam 3 : 20. DOI: 10.1186/s40550-016-0043-5.
Post DE. 1997. Food-borne pathogens monograph number I Salmonella. Oxoid Limited, Hampshire, England.

Terfassa A, Jidda M. 2018. Prevalence and Antibiotics Susceptibility Pattern of Salmonella and Shigella Species among Diarrheal Patients Attending Nekemte Referral Hospital, Oromia, Ethiopia. Int J Microbiol. https://doi.org/10.1155/2018/9214689

Upadhyay BP, Utrarachkij F, Thongshoob J, Mahakunkijcharoen Y, Wongchinda N, Suthienkul O, Khusmith S. 2010. Detection of Salmonella invA gene in shrimp enrichment culture by polymerase chain reaction. Southeast Asian J Trop Med Public Health 41 (2):42635.

Yhils N, Bassey E. 2015. Critical segments in the dissemination and transmission of Salmonella species from poultry production in Calabar, Nigeria. Sci J Public Health 3 (2): 168-174. DOI: 10.11648/j.sjph.20150302.13 